\title{
IMPLEMENTASI PEMBELAJARAN MEMBACA BERITA MELALUI PEMODELAN
}

\author{
Ninik Sukaryani \\ Madrasah Aliyah Negeri 1 Bojonegoro \\ Jl. Monginsidi No 150 Tlp (0353) 881320 Bojonegoro \\ E-MAIL: niniksukaryani@yahoo.co.id
}

\begin{abstract}
Abstrak: Jenis penelitian ini adalah penelitian tindakan kelas. Subjek penelitian ini adalah siswa kelas XI IPS 1 yang berjumlah 30 siswa tahun pelajaran 2014/2015 semester 2. Pelaksanaan penelitian tindakan kelas ini dilakukan selama dua siklus, yang terdiri atas rangkaian empat kegiatan yang dilakukan dalam siklus berulang. Empat kegiatan utama yang ada pada setiap siklus, yaitu (a) perencanaan, (b) pelaksanaan, (c) pengamatan, dan (d) refleksi. Berdasarkan hasil penelitian, dapat diketahui bahwa: Pelaksanaan pemodelan di Madrasah Aliyah Negeri 1 Bojonegoro adalah baik. Kemampuan membaca berita pada siswa kelas XI IPS 1 Madrasah Aliyah Negeri 1 Bojonegoro adalah baik. Berdasarkan kemampuan membaca berita melalui pelaksanaan pemodelan pada siswa kelas XI IPS 1 Madrasah Aliyah Negeri 1 Bojonegoro, pada siklus pertama persentase ketuntasan belajar sebesar 56,67\%, sedangkan pada siklus kedua persentase ketuntasan belajar sebesar 80\%. Dari data tersebut di atas, hasil belajar mulai siklus I sampai dengan siklus II terus mengalami peningkatan yang cukup signifikan.
\end{abstract}

Key words: reading, news, modeling

Abstrak: Type of the research is classroom action research. The subject of this research is the students class XI IPS 1 has 30 students in academic year of 2014/2015 semester 2. Implementation of this research is to do 2 cycles, which consist of four activities, that (a) planning, (b) implementing, (c) observing, (d) reflecting. Based on the result of research, it can be known that: The competency of reading news students class XI IPS 1 Madrasah Aliyah Negeri 1 Bojonegoro is good. Implementation of modeling students class XI IPS 1 Madrasah Aliyah Negeri 1 Bojonegoro is good. Based on the computation of the implementation of modeling to increase the competency of reading news students class XI IPS 1 Madrasah Aliyah Negeri 1 Bojonegoro, the first cycles of mastery learning is $56.67 \%$, while for the second cycle of mastery learning is $80 \%$. From the data, the mastery learning from the first cycle to the second cycle has significant increasing. So, it can be said that the implementation of modeling can increase the competence of reading news.

\section{PENDAHULUAN}

Perkembangan ilmu pengetahuan dan teknologi menuntut terciptanya masyarakat yang gemar belajar. Proses belajar yang efektif antara lain dilakukan melalui membaca. Masyarakat yang gemar membaca memperoleh pengetahuan dan wawasan baru yang akan semakin meningkatkan kecerdasannya sehingga mereka lebih mampu menjawab tantangan hidup pada masa-masa mendatang.

Kemampuan membaca merupakan sesuatu yang vital dalam suatu 
masyarakat terpelajar. Namun, anak-anak yang tidak memahami pentingnya belajar membaca tidak akan termotivasi untuk belajar. Belajar membaca merupakan usaha yang terus-menerus, dan anak-anak yang melihat tingginya nilai (value) membaca dalam kegiatan pribadinya akan lebih giat belajar dibandingkan dengan anak-anak yang tidak menemukan keuntungan dari kegiatan membaca.

Membaca semakin penting dalam kehidupan masyarakat yang semakin kompleks. Setiap aspek kehidupan melibatkan kegiatan membaca. Tandatanda jalan mengarahkan orang yang berpergian sampai pada tujuannya, menginformasikan pengemudi mengenai bahaya di jalan, dan mengingatkan aturan-aturan lalu lintas. Pengusaha katering tidak perlu harus pergi ke pasar untuk mengetahui harga bahan-bahan yang akan dibutuhkan. Dia cukup membaca surat kabar untuk mendapat informasi tersebut. Kemudian, dia bisa merencanakan apa saja yang harus dibelinya disesuaikan dengan informasi tentang bahan yang dibutuhkannya.

Selain itu, kemampuan membaca merupakan tuntutan realitas kehidupan sehari-hari manusia. Beribu judul buku dan berjuta koran diterbitkan setiap hari. Ledakan informasi ini menimbulkan tekanan pada guru untuk menyiapkan bacaan yang memuat informasi yang relevan untuk siswa-siswanya. Walaupun tidak semua informasi perlu dibaca, tetapi jenis-jenis bacaan tertentu yang sesuai dengan kebutuhan dan kepentingan kita tentu perlu dibaca.

Pengajaran membaca pada hakekatnya adalah seperangkat usaha formal-konvensional yang dilakukan secara sadar berencana untuk membina siswa dalam membaca. Rumusan ini menggambarkan banyak hal. Pertama, pengajaran membaca mencakup berbagai macam usaha yang taut-bertaut satu dengan yang lainnya sehingga merupakan suatu perangkat usaha. Kedua, pengajaran membaca merupakan usaha formal, yaitu usaha resmi yang melembaga sifatnya dalam bidang pendidikan. Selain formal, pengajaran membaca juga merupakan usaha konvensional, yaitu usaha yang selama ini biasa serta umum ditempuh dalam bidang pendidikan untuk membina siswa dalam membaca.

Berdasarkan hasil observasi pra penelitian kemampuan membaca berita pada siswa kelas XI IPS 1 dari 30 siswa terdapat 17 siswa atau $56,67 \%$ yang mendapatkan nilai di bawah KKM (Kriteria Ketuntasan Minimal) yaitu 77. Dari data tersebut, dapat diketahui bahwa kemampuan membaca berita siswa masih jauh dari kategori baik. Oleh karena itu, guru diharapkan dapat menemukan penyelesaian masalah tersebut untuk meningkatkan prestasi belajar. Perubahan strategi dan model pembelajaran mutlak dilakukan. Salah satu model pembelajaran yang dapat diaplikasikan dalam pembelajaran membaca adalah pemodelan (modeling).

Dalam pelaksanaan pembelajaran membaca berita dengan pemodelan dilakukan dengan cara mengundang penyiar berita di radio atau televisi. Dengan cara tersebut diharapkan siswa dapat mengetahui secara detail bagaimana cara membaca berita yang baik dan benar.

Berdasarkan penjelasan di atas, penulis ingin mengadakan suatu penelitian dalam bentuk penelitian tindakan kelas yang berjudul "Implementasi Pembelajaran Membaca Berita melalui Pemodelan pada Siswa Kelas XI IPS 1 Madrasah Aliyah Negeri 1 Bojonegoro." 


\section{METODE PENELITIAN}

Jenis penelitian ini adalah penelitian tindakan kelas. Menurut John Elliot bahwa yang dimaksud dengan PTK ialah kajian tentang situasi sosial dengan maksud untuk meningkatkan kualitas tindakan di dalamnya (Elliot, 1982). Seluruh prosesnya, telaah, diagnosis, perencanaan, pelaksanaan, pemantauan, dan pengaruh menciptakan hubungan yang diperlukan antara evaluasi diri dari perkembangan profesional.

Penelitian ini dilakukan di Madrasah Aliyah Negeri 1 Bojonegoro. Adapun yang menjadi subjek penelitian ini adalah siswa kelas XI IPS 1 yang berjumlah 30 siswa tahun pelajaran 2014/2015 semester 2 .

Pelaksanaan penelitian tindakan kelas ini dilakukan selama dua siklus, yang terdiri atas rangkaian empat kegiatan yang dilakukan dalam siklus berulang. Empat kegiatan utama yang ada pada setiap siklus, yaitu (a) perencanaan, (b) pelaksanaan, (c) pengamatan, dan (d) refleksi.

\section{HASIL PENELITIAN DAN PEMBAHASAN}

Berdasarkan hasil observasi siklus I, dapat diketahui bahwa nilai rata-rata kemampuan membaca berita sebesar 72,77. Selain itu, juga dapat diketahui bahwa jumlah siswa yang mendapatkan nilai di atas atau sama dengan KKM (kriteria ketuntasan minimal) sebanyak 17 siswa atau 56,67\%. Sedangkan yang mendapatkan nilai di bawah KKM sebanyak 13 siswa atau 43,33\%.

Berdasarkan hasil pengamatan ternyata masih terdapat siswa yang belum aktif untuk melakukan pembelajaran secara optimal. Selain itu, masih banyak siswa yang tidak berani bertanya maupun menjawab pertanyaan yang diberikan. Sehingga perlu adanya penguasaan konsep, sikap ilmiah dan keterampilan ilmiah harus seimbang untuk mengaktifkan siswa.

Dari hasil siklus pertama pelaksanaan pemodelan belum dapat dilakukan secara optimal. Maka pada siklus kedua ini diadakan perbaikan agar pelaksanaan pemodelan tersebut dapat dilaksanakan sebagaimana mestinya.

Berdasarkan hasil observasi, dapat diketahui bahwa nilai rata-rata kemampuan membaca berita sebesar 75,07. Dari hasil penelitian, juga dapat diketahui bahwa jumlah siswa yang mendapatkan nilai di atas atau sama dengan KKM sebanyak 24 siswa atau $80 \%$. Kemudian yang mendapatkan nilai di bawah KKM sebanyak 6 siswa atau $20 \%$.

Pada siklus kedua ini terjadi peningkatkan kemampuan membaca yang cukup signifikan. Hal ini disebabkan siswa mulai berani untuk membaca seperti yang dilakukan oleh model.

Penelitian ini merupakan upaya membantu siswa meningkatkan kemampuan membaca berita melalui pemodelan pada siswa kelas XI IPS 1 Madrasah Aliyah Negeri 1 Bojonegoro.

Ternyata hasil evaluasi menunjukkan perbaikan yang cukup signifikan. Dengan demikian proses perbaikan pembelajaran yang dilakukan peneliti dapat terlaksana sesuai dengan tujuan perbaikan sehingga kemampuan membaca berita mengalami peningkatan melalui pemodelan.

Dari hasil kemampuan membaca berita siswa kelas XI IPS 1 Madrasah Aliyah Negeri 1 Bojonegoro, dari siklus I sampai dengan siklus II terus mengalami peningkatan yang cukup signifikan. Dengan demikian dapat dikatakan bahwa pelaksanaan pemodelan dapat meningkatkan kemampuan membaca berita.

Sepengetahuan penulis belum ada penelitian terdahulu yang sama persis 
dengan penelitian yang penulis lakukan, kecuali yang berbeda variabel baik itu variabel $\mathrm{x}$ ataupun $\mathrm{y}$. Berikut penulis sajikan beberapa penelitian terdahulu di antaranya.

Rustiyah dalam penelitiannya yang berjudul "Peningkatan Kemampuan Membaca Berita melalui Metode Drill Siswa Kelas XI SMA Negeri 1 Kalitidu Kabupaten Bojonegoro" pada tahun 2014, didapatkan hasil bahwa terdapat pengaruh yang signifikan antara kemampuan membaca berita dengan metode drill.

Siviana Dewi yang melaksanakan penelitian pada tahun 2010 dengan judul "Implementasi Metode Simulasi dalam Meningkatkan Kemampuan Membaca Berita Siswa Kelas XI SMA Negeri 1 Jombang" didapatkan hasil dari perhitungan yang ada ternyata semakin baik pelaksanaan simulasi, semakin baik pula kemampuan membaca berita, dari hasil perhitungan korelasi sebesar 0,891, hal ini berarti bahwa terdapat pengaruh yang cukup signifikan antara metode simulasi dengan kemampuan membaca berita.

Perbedaan antara penelitian ini dengan penelitian terdahulu sudah jelas, yaitu pada penelitian ini untuk mengetahui kemampuan membaca berita melalui pemodelan siswa kelas XI IPS 1 Madrasah Aliyah Negeri 1 Bojonegoro. Sedangkan penelitian terdahulu dari variabel $x$ dan $y$ berbeda. Sehingga penelitian ini, bukan plagiat dari penelitian sebelumnya. Apabila objek dan variabel penelitian berbeda, maka dapat dipastikan hasilnya juga akan berbeda.

\section{PENUTUP}

Berdasarkan hasil penelitian, maka penulis dapat membuat suatu simpulan antara lain:
1. Pelaksanaan pemodelan di Madrasah Aliyah Negeri 1 Bojonegoro adalah baik.

2. Kemampuan membaca berita pada siswa kelas XI IPS 1 Madrasah Aliyah Negeri 1 Bojonegoro adalah baik.

3. Berdasarkan kemampuan membaca berita melalui pelaksanaan pemodelan pada siswa kelas XI IPS 1 Madrasah Aliyah Negeri 1 Bojonegoro, pada siklus pertama persentase ketuntasan belajar sebesar 56,67\%, sedangkan pada siklus kedua persentase ketuntasan belajar sebesar $80 \%$. Dari data tersebut di atas, hasil belajar mulai siklus I sampai dengan siklus II terus mengalami peningkatan yang cukup signifikan. Dengan demikian dapat dikatakan bahwa pelaksanaan pemodelan dapat meningkatkan kemampuan membaca berita.

Dari penjelasan di atas, penulis dapat memberikan saran yang dapat berguna untuk siswa dan guru, yaitu:

1. Penggunaan pemodelan diharapkan dapat dilaksanakan dengan sebaikbaiknya oleh guru terutama mata pelajaran bahasa Indonesia pokok bahasan berita.

2. Siswa diharapkan untuk terus meningkatkan belajarnya, sehingga tingkat kemampuan membaca berita menjadi semakin baik.

3. Mengingat pelaksanaan pemodelan mempunyai peranan yang signifikan terhadap peningkatan kemampuan membaca berita, oleh karena itu, guru diharapkan untuk menggunakan pemodelan sebagai strategi pembelajaran.

\section{DAFTAR PUSTAKA}

Akhadiah, Sabarti, dkk. (1992) Bahasa Indonesia I, Departemen Pendidikan dan Kebudayaan, Jakarta. 
Anwar, Rosihan. (1984) Bahasa Jurnalistik dan Komposisi, Pradnya Paramita, Jakarta.

Aqib, Zainal. (2006) Penelitian Tindakan Kelas, Yrama Widya, Bandung.

Arifin, E. Zaenal, dan Tasai, S. Amran. (2008) Cermat Berbahasa Indonesia untuk Perguruan Tinggi, Akademika Pressindo, Jakarta.

Arikunto, Suharsimi., Suhardjono, dan Supardi. (2007) Penelitian Tindakan Kelas, Bumi Aksara, Jakarta.

Boediono. (2002) Kurikulum dan Hasil Belajar Bahasa Indonesia, Balitbang Depdiknas, Jakarta.

Departemen Pendidikan dan Kebudayaan. (2000) Kamus Besar Bahasa Indonesia, Balai Pustaka, Jakarta.

Dhieni, Nurbiana, dan Fridani, Lara. (2008) Perkembangan Berbicara dan Menulis, Universitas Terbuka, Jakarta.

Indrawati. (2008) Bahasa dan Sastra Indonesia 2 : Untuk SMA/MA Program IPA-IPS Kelas XI, Jakarta: Pusat Perbukuan Depdiknas.

Keraf, Gorys. (2000) Tata Bahasa Indonesia, Nusa Indah, Ende.

Mulyati, Yeti. (1999) Pendidikan Bahasa dan Sastra Indonesia di Kelas
Tinggi, Universitas Terbuka, Jakarta.

Muslich, Masnur. (2008) Fonologi Bahasa Indonesia, Bumi Aksara, Jakarta.

Nasution, Noehi. (1996) Psikologi Pendidikan, Universitas Terbuka, Jakarta.

Nurhadi, Burhan Yasin, dan Agus Gerrad Senduk. (2004) Pembelajaran Kontekstual dan Penerapannya dalam KBK, Universitas Negeri Malang, Malang.

Rahim, Farida. (2007) Pengajaran Membaca di Sekolah Dasar, Bumi Aksara, Jakarta.

Saliwangi, Basennang. (1989) Pengantar Strategi Belajar Mengajar Bahasa Indonesia, IKIP Malang, Malang.

Suparni. (1986) Penuntun Pelajaran Bahasa dan Sastra Indonesia, Ganeca Exact, Bandung.

Supriyadi. (1996) Pendidikan Bahasa Indonesia 4, Depdiknas, Jakarta.

Tarigan, Djago. (1998) Pendidikan Bahasa dan Sastra Indonesia di Kelas Rendah, Depdiknas, Jakarta.

Verhaar. (2000) Pengantar Linguistik, Gajah Mada University Press, Yogyakarta. 
